\title{
Use of color lights for the detection of anomalies in quality systems
}

\author{
Báez $\mathrm{G}^{\mathrm{a}^{*}}$, De la Vega $\mathrm{E}^{\mathrm{b}}$, Castro $\mathrm{C}^{\mathrm{c}}$ and Elizarraras $\mathrm{R}^{\mathrm{d} .}$ \\ ${ }^{a}$ Universidad Autónoma de Sinaloa, Ángel Flores Colonia Centro, Culiacán Sinaloa, México. \\ b Instituto Tecnológico de Hermosillo, e_delavega_mx@yahoo.com, Sonora, México. \\ ${ }^{c}$ Universidad Autónoma Indígena de México, klaudy_00@hotmail.com, Sinaloa, México. \\ d Instituto Tecnológico de Hermosillo, rocioelizarraras2@hotmail.com,Sonora, México.
}

\begin{abstract}
The importance of eye care in the industry is a first level topic, due to most of the assembly and manufacturing aimed companies of various products that require direct health care of their employees, specially eye care. The lighting system, the lamp features and job tasks are factors that impact over the visual performance of the worker. Each of these factors, either by themselves or in conjunction, influences the visual performance of the employee, and therefore its safety and efficacy. Some of the reported symptoms are: problem of visual fixation, eye redness, tearing, headache, blurred vision, eyelids heaviness and dry eyes, [7]. The research was developed with 48 people, 27 male and 21 female, in the range of ages of 17 to 58 years old. In the experiment were used illumination system base on Diode Emitting lights (LED's) of five different colors (White, Blue, Green, Red and Yellow), the reason of use of LED's it is because are source of monochromatic light, also it is also saving power light and low heating dissipation.
\end{abstract}

Keywords: Visual Fatigue, anomaly detection, light emitting Diodes (LED)

\section{Introduction}

The work environment is one of the key elements that impact on the health, performance and comfort of the workers, [11]. A poor lighting can potentially increase the chance of mistakes and accidents, can lead to visual fatigue, with all of the damages that this represent on people's health, for example, eye issues (dryness, itching), headache, fatigue, irritability, etc.

Human beings have an extraordinary ability to adapt to their environment. Of all the types of energy that humans can use, light is the most important. Light is an essential element of our capacity to see and it is necessary to appreciate the shape, color and perspective of the objects that surround us in our daily living. Therefore the visual system is a major sense of the human being, due to most of the tasks that are performed with the help of the eyes; it is also stated that $80 \%$ of the information we obtain through our senses we get it by the sight [12].
There are over 284 million people visually impaired worldwide: 39 million are blind and 245 have low vision. Most of the vision impairment is caused by refractive errors (myopia, hypermetrophy and astigmatism), it means that we are facing a major public health problem [13].

According to the Mexican National Institute of Statistics, Geography and Informatics (INEGI) visual problems are the second leading cause of disability in Mexico. Between 25 and 30\% of the Mexican population have a refraction deficiency, which is manifested at different ages and can develop into a disabling factor according the Mexican Social Security Institute [6].

The Objective is to determine the favorable visual environment for the appreciation of defects in metal parts by using lights of different colors. To find the right color of light to detect scratches, dings, chop and chip on metal pieces.

\footnotetext{
*Corresponding author. E-mail: gracerandy@gmail.com. Phone: (52) 6878723874 Fax: (52) 6878725506
} 


\section{Methodology}

The following describes the methodology used to conduct the research:

1. This research used LEDs color lamps: white, green, blue, red and yellow.



Figure 1. LED lamps

2. The black light is used in quality control for the detection of anomalies. Due to the phenomenon called fluorescence the anomalies are highlighted when they are exposed to black light.

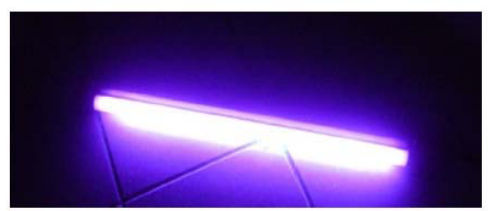

Figure 2. Black light

3. The material used in this research were samples of automotive body parts (18 pieces) which were provided by an automotive company for visual inspection with LED's light of different colors.

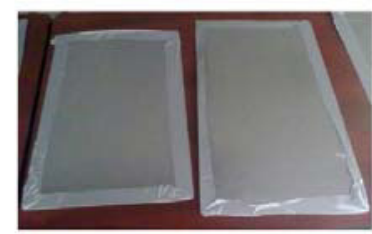

Figure 3. Metal sheets to inspect

4. The metal sheets will be listed from 1 to 18 with a small number that subjects cannot see easily.

5. Some of the 18 metal sheets to be used will have some defects such as: scratches, dings, chop and chip, while others will be presented in perfect condition.
Table 1. Expected results in each metal sheet

\begin{tabular}{|c|c|c|c|}
\hline $\begin{array}{c}\text { Metal } \\
\text { sheets }\end{array}$ & $\begin{array}{c}\text { Expected } \\
\text { results }\end{array}$ & $\begin{array}{c}\text { Metal } \\
\text { sheets }\end{array}$ & $\begin{array}{c}\text { Expected } \\
\text { results }\end{array}$ \\
\hline 1 & Chop & 10 & Dings \\
\hline 2 & Scratch, chop & 11 & Good \\
\hline 3 & Dings, scratch & 12 & Dings, scratch \\
\hline 4 & Good & 13 & Good \\
\hline 5 & Dings & 14 & Dings, scratch \\
\hline 6 & Scratch & 15 & Scratch \\
\hline 7 & Dings, scratch & 16 & Dings \\
\hline 8 & Good & 17 & Good \\
\hline 9 & Scratch, chip & 18 & Dings \\
\hline
\end{tabular}

6. The 18 metal sheets were randomly assigned to the 48 people included in this case of study.

7. It will be used the format shown for recording results of each experiment.

\section{Experiment}

3. Laboratory tests (Experimental phase):

3.1 The room windows will be blinded.

3.2 The experiment will be performed with 48 subjects.

3.3 All unnecessary obstructions in the visual field will be removed.

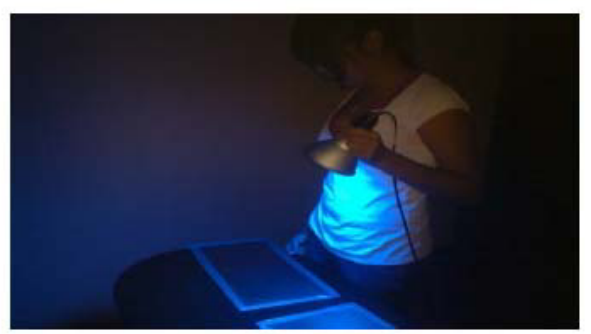

Figure 4. Visual inspection

The average inspection time is approximately 30 seconds per metal sheet. Subjects inspected the 18 metal sheets using one particular color of light, and then he/she would take a break and perform the inspection of the 18 sheets with a new color of light. Each subject performs a total of 108 (18 sheets x 6 colors) inspections in about 1 hour. Finally each subject was asked: which is the best color of light to find anomalies in metal sheets? 


\section{Results and discussion}

The results are $35 \%$ of people said that the best color to find anomalies is green, followed by blue with $21 \%$, white and yellow with $17 \%$ and finally the red with $10 \%$.

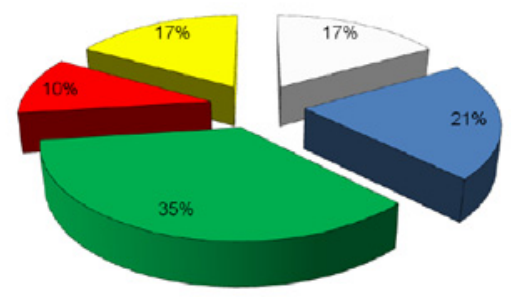

Figure 5. Results of appreciation using different colors of light

The color of light best to identify scratches was green $(67.6 \%)$ of the scratches were identified, for the dings the best color was blue $(69.7 \%)$, for the chops the best color was blue again $(94.9 \%)$ and finally the sheets were best identified using green light (98.6\%). See Table 2.

\begin{tabular}{|c|c|c|c|c|c|}
\multicolumn{1}{c|}{ Table 2. Experiment results } \\
\cline { 2 - 6 } \multicolumn{1}{c|}{} & $\begin{array}{l}\text { WHITE } \\
\text { LIGHT }\end{array}$ & $\begin{array}{l}\text { BLUE } \\
\text { LIGHT }\end{array}$ & $\begin{array}{l}\text { GREEN } \\
\text { LIGHT }\end{array}$ & $\begin{array}{c}\text { RED } \\
\text { LIGHT }\end{array}$ & $\begin{array}{c}\text { YELLOW } \\
\text { LIGHT }\end{array}$ \\
\hline SCRATCH & 0.640046 & 0.66088 & 0.675926 & 0.633102 & 0.6412037 \\
\hline DINGS & 0.668981 & 0.696759 & 0.663194 & 0.668981 & 0.6736111 \\
\hline CHOP & 0.946759 & 0.949074 & 0.946759 & 0.943287 & 0.9444444 \\
\hline CHIP & 0.980324 & 0.982639 & 0.986111 & 0.978009 & 0.9826389 \\
\hline
\end{tabular}

It was determined that the LED lamps (Light Emitting Diode) green and blue are the best in the detection of scratches, chops, and chips for visual inspection of automotive body parts and that better results were obtained in the analysis data.

One of the reasons why you should pay attention to the type of lighting used in the workplace Is be- cause people who perform visual inspection are at risk of Asthenopy (Visual Fatigue), which is a latent uneasiness in most companies, If not treated, can lead to serious defects in vision, such as decreased visual acuity, defective color vision and accidents.

\section{References}

[1] M. Blouin \& C. Bergeron, Diccionario de la readaptación. Tomo 2: Términos de intervención y de ayudas técnicas. Laboratorio de Informática y de terminología de la readaptación y de la integración social. Quebec: 1997.

[2] J.R. Burke. Fisica: la naturaleza de las cosas. México, D F.: International Thompson Editores. 1998.

[3] M. Chantler, M Schmidt, \& M. Petrou, The effect of iluminante rotation on texture filtres. In 7 th European Conference on Computer vision Dinamarca, 2002, pp. 289 304.

[4] J. Cortés Díaz, Seguridad e Higiene del Trabajo. Técnicas de prevención de riesgos laborales. Alfaomega Grupo Editor, S.A. de C.V. México D.F. 2002.

[5] F. Farrer Velázquez, \& M. Lozano, Manual de Ergonomía. Madrid: 1994

[6] Instituto Mexicano del Seguro Social IMSS, recuperado el 14 de agosto de 2010.

Http://www.imss.gob.mx/NR/rdonlyres/4BF7B65423564C5A BB2D- E9031DFE2C2F/0/240310Com049.pdf

[7] J.A. Llaneza. Ergonomía y psicosociología aplicada: Manual para la formación del especialista.España: Lex Nova. S.A. 2006

[8] J.M. Medina, Fundamentos de Ergonomía, Instituto Tecnológico de Mérida, Mérida Yucatán 2000.

[9] P.R. Móndelo and E. Gregori, Ergonomía 3, Diseño de puestos. Alfaomega, Grupo Editor S.A.de C.V. 2001

[10] P.R. Móndelo and E. Gregori, Ergonomía 4, El trabajo en Oficinas. Alfaomega, Grupo Editor S.A.de C.V. 2002

[11]C. Ramírez Cavassa, Ergonomía y Productividad, México: Editorial Limusa S.A.de C.V. 2006

[12]F. Ramos Pérez, \& A. Hernández Calleja, Iluminación en la Enciclopedia de Salud y Seguridad en el Trabajo, Vol. II, parte VI, Ginebra Suiza: Organización Internacional del trabajo 1997.

[13] Whorld Health Organization (WHO) http://www.who.int/mediacentre /factsheets/fs282/en /index/.html 2011 